\title{
Penerapan Model ELPSA dengan Bantuan Alat Peraga Geoboard untuk Meningkatkan Aktivitas dan Hasil Belajar Siswa pada Materi Bangun Datar
}

\author{
Wahyuddin \\ SMP Negeri 2 Dompu, Kabupaten Dompu - Provinsi NTB \\ *Corresponding Author. Email: Wahyudincandi@gmail.com
}

\begin{abstract}
The purpose of this research is to increase the activity and student learning outcomes on the flat shape material with the ELPSA model using geoboard props. This research method uses classroom action research. The subjects of this study were students of class VII A of SMP Negeri 2 Dompu, totaling 28 people. Data collection techniques using questionnaires, and tests. While the data analysis technique is descriptive quantitative and qualitative. The results of this study indicate that the application of the ELPSA model with the help of a geoboard tool on flat-shaped materials can improve student activities and learning outcomes. This is evidenced by the average increase in activity data of $55.36 \%$ in the first cycle, to $63.61 \%$ in the second cycle and increased to $74.49 \%$ in the third cycle. Data on the average increase in student learning outcomes from $55.06 \%$ in the first cycle, to $61.90 \%$ in the second cycle and increased to $67.41 \%$ in the third cycle. Based on the results of this study, teachers should always innovate to be able to motivate students' interest in learning and improve the quality of learning with varied learning models and appropriate teaching aids, so that student learning outcomes can be maximized.
\end{abstract}

\begin{abstract}
Abstrak: Tujuan dari penelitian ini adalah untuk meningkatkan aktivitas dan hasil belajar siswa pada materi bangun datar dengan model ELPSA menggunakan alat peraga geoboard. Metode penelitian ini menggunakan penelitian tindakan kelas. Subyek penelitian ini adalah siswa kelas VII A SMP Negeri 2 Dompu yang berjumlah 28 orang. Teknik pengumpulan data menggunakan angket, dan tes. Sedangkan teknik analisis datanya adalah deskriptif kuantitatif dan kualitatif. Hasil penelitian ini menunjukkan bahwa penerapan model ELPSA dengan bantuan alat geoboard pada materi bangun datar dapat meningkatkan aktivitas dan hasil belajar siswa. Hal ini dibuktikan dengan data peningkatan aktivitas rata-rata $55,36 \%$ pada siklus I, menjadi $63,61 \%$ pada siklus II dan meningkat menjadi $74,49 \%$ pada siklus III. Data peningkatan rata-rata hasil belajar siswa dari $55,06 \%$ pada siklus I, menjadi $61,90 \%$ pada siklus II dan meningkat menjadi $67,41 \%$ pada siklus III. Berdasarkan hasil penelitian ini hendaknya guru selalu berinovasi untuk dapat memotivasi minat belajar siswa dan memperbaiki kualitas pembelajaran dengan model pembelajaran yang bervariasi dan alat peraga yang sesuai, sehingga hasil belajar siswa bisa maksimal.
\end{abstract}

Article History

Received: 10-08-2021

Revised: 07-09-2021

Accepted: 20-09-2021

Published: 05-10-2021

\section{Key Words:}

ELPSA, Geoboard Props, Learning Activity, Learning Outcomes.

\section{Sejarah Artikel}

Diterima: 10-08-2021

Direvisi: 07-09-2021

Disetujui: 20-09-2021

Diterbitkan: 05-10-2021

\section{Kata Kunci:}

ELPSA, Peraga Geoboard, Aktivitas, Hasil Belajar.

How to Cite: Wahyuddin, W. (2021). Penerapan Model ELPSA dengan Bantuan Alat Peraga Geoboard untuk Meningkatkan Aktivitas dan Hasil Belajar Siswa pada Materi Bangun Datar. Jurnal Paedagogy, 8(4), 497-505. doi:https://doi.org/10.33394/jp.v8i4.4130

d.

https://doi.org/10.33394/jp.v8i4.4130

This is an open-access article under the CC-BY-SA License.

\section{Pendahuluan}

Matematika sampai saat ini masih menjadi salah satu pelajaran yang penting dan digunakan di hampir semua bidang. Hal ini dikarenakan Matematika masih tetap digunakan dalam banyak hal. Dalam tingkatan pendidikan dasar sampai perguruan tinggi, pelajaran Matematika masih dipelajari. Namun, banyak kendala yang dianggap sulit oleh para siswa dalam mempelajari Matematika, karena objek matematika yang abstrak menggunakan banyak 
rumus (Utami dalam Husna et al., 2021; Baharudin, 2015; Annisa et al, 2021). Berdasarkan hasil survei awal ujian tengah semester pada siswa kelas VII A SMP Negeri 2 Dompu dari 28 orang siswa sebagai subyek penelitian menunjukkan bahwa nilai rata-rata Matematika masih rendah yaitu 57,70 dengan Kriteria Ketuntasan 60, dan 14 siswa memperoleh nilai di bawah KKM. Proses pembelajaran dengan tidak baik melibatkan aktivitas siswa akan berakibat pada tidak optimalnya pemusatan perhatian pada kemampuan yang harus dikuasainya, siswa sering berada dalam situasi tertekan.

Siswa tidak mendapat kesempatan untuk melakukan eksplorasi lingkungan sekitar, sehingga membuat mereka terasing dengan lingkungannya, tidak memiliki kemampuan untuk mencari dan menemukan informasi yang diperlukannya, dan siswa hanya terfokus pada pengembangan ranah kognitif saja dan kurang memperhatikan aspek afeksi (emosional, mental, keterampilanm, dan spiritual). Padahal, kondisi pembelajaran seperti itu akan sulit diharapkan untuk mampu membuat siswa memiliki kemampuan berpikir kritis, kreatif, inovatif, serta memiliki karakter dan watak untuk mengahadapi berbagai permasalahan dalam kehidupannya sehari-hari.

Dari kondisi tersebut menunjukkan guru merupakan salah satu faktor yang dominan penyebab kesulitan belajar siswa. Selama ini guru mendominasi pembelajaran dengan ceramah dan tidak melibatkan siswa secara aktif dalam pembelajaran. Guru jarang menggunakan media pembelajaran interaktif dan menarik. Akibatnya siswa pasif karena tidak diberi kesempatan untuk berpikir dan menemukan konsep sendiri. Pembelajaran sangat membosankan dan tidak efektif, dan berdampak pada rendahnya hasil belajar Matematika.

Di dalam Kurikulum 2013 setiap pembelajarannya siswa dituntut untuk aktif, kreatif, dan inovatif, serta kemampuan berpikir siswa dalam mempelajari setiap konsep mata pelajaran harus berkembang sesuai dengan umur dan karakter siswa. Menyikapi hal tersebut dalam pembelajaran Matematika perlu di munculkan ide-ide kreatif dan inovatif untuk meningkatkan kemampuan berpikir dan kreativitas dengan pembelajaran dengan bantuan media pembelajaran yang nantinya akan berdampak pada hasil pembelajaran. Banyak alat peraga yang dapat dimanfaatkan untuk mendukung pembelajaran, salah satunya adalah alat peraga geoboard (papan berpaku).

Menurut (Imas, 2017) Alat peraga geoboard memiliki pengaruh terhadap hasil belajar siswa pada mata pelajaran Matematika, Hal menunjukan bahwa dengan penggunaan alat peraga geoboard lebih efektif dalam meningkatkan hasil belajar siswa. Peneliti telah melakukan pembelajaran Matematika yang inovatif tanpa alat peraga yang dapat langsung diperagakan oleh siswa dan pelaksanaan pembelajarannya masih terbatas pada penggunaan model pembelajaran kooperatif dan melalui gambar. Pembelajaran kooperatif dengan STAD (Student Team Achievement Divisions), dan hanya mengerjakan latihan-latihan soal setelah materi disampaikan.

Berdasarkan refleksi dan evaluasi, pembelajaran Matematika yang telah dilakukan ternyata menjadi kurang menarik jika terlalu sering dilakukan dan tanpa bantuan media atau alat peraga. Pelaksanaan pembelajaran Matematika yang dilakukan jangan hanya terpaku dengan satu model pembelajaran tertentu saja. Siswa akan merasa jenuh, bosan dengan model pembelajaran yang tidak bervariasi juga media atau alat peraganya, yang akan berakibat siswa kurang dapat membangun kemampuan berpikir matematik. Untuk itu, perlu dilaksanakan variasi pembelajaran dengan bantuan alat peraga geoboard dan menggunakan model pembelajaran ELPSA (Experiences, Language, Pictures, Symbols, Applicatioan) agar dapat menghilangkan kejenuhan dan dapat meningkatkan aktivitas belajar pada siswa. 
Untuk memperbaiki dan meningkatkan keterlibatan atau keaktifan siswa dalam pembelajaran adalah sebagai berikut : 1) Mengenali dan membantu siswa yang kurang terlibat, 2) Menyiapkan siswa secara tepat, 3) Menyesuaikan pengajaran dengan kebutuhankebutuhan individual siswa. Aktivitas siswa dalam prose pembelajaran merupakan salah satu indikator adanya kegiatan siswa untuk belajar (Supinah, 2015). Kegiatan-kegiatannya adalah mengarah pada proses belajar seperti bertanya, mengajukan pendapat, megerjakan tugastugas, dapat menjawab pertanyaan guru dan bisa bekerja sama dengan siswa lain, serta tanggung jawab terhadap tugas yang diberikan.

Model Pembelajaran ELPSA (Experiences, Language, Pictures, Symbols, Applicatioan) dikembangkan oleh tim RIPPLE (Research Institute for Professional Practice, Learning \& Education) yang diketuai oleh Prof Tom Lowrie dari Charles Sturt University Australia. ELPSA merupakan sebuah kerangka desain pembelajaran yang dibuat secara khusus untuk konteks Indonesia sebagai hasil dari analisis data video TIMSS (Wijaya, 2014). Kerangka ELPSA dimulai dari menghubungkan pengalaman siswa sebelumnya ke pembelajaran baru, memberi siswa kesempatan untuk mengekspresikan temuan mereka sendiri, dan membangun visual, memikirkan siswa untuk presentasi ide menggunakan simbol, sehingga siswa bisa menganggap matematika sebagai subjek yang bermakna daripada yang sulit (Johar, 2016).

Untuk membelajarkan siswa secara efektif, kerangka kerja ELPSA adalah alat yang praktis dan mudah dipahami untuk merancang suatu pembelajaran Matematika dalam mengembangkan konsep secara bermakna dan eksplisit, meningkatkan kualitas pembelajaran, dan siswa dapat memahami Matematika lebih komprehensif (Patahudin, 2015). Selain itu, pembelajaran Matematika yang selama ini penulis lakukan tidak banyak memberikan kesempatan kepada siswa untuk meningkatkan kemampuan berpikir dalam meningkatkan kompetensinya sesuai dengan tuntutan dalam pembelajaran. Hal tersebut sebagai akibat dari pembelajaran yang tidak bermakna, siswa hanya diberi rumus tanpa dijelaskan mengapa rumus itu digunakan. Pola pembelajaran semacam ini membuat siswa tidak memahami materi yang diajarkan sehingga berakibat pada rendahnya hasil belajar.

Oleh karena itu, diperlukan pembelajaran yang menarik sehingga siswa dapat memperoleh pemahaman tidak hanya menghafal rumus. Pembelajaran memiliki proses yang berkesinambungan untuk mencapai tujuan pembelajaran yang disebut aktivitas belajar. Hasil belajar sering dijadikan tolok ukur dalam penilaian prestasi akademik dan merupaka cerminan dari kemampuan yang dimiliki siswa selama proses pembelajaran juga salah satu indikator tercapainya tujuan pembelajaran. Sebagai alternatif menjawab tantangan tersebut telah dilakukan upaya menciptakan pembelajaran yang menarik dengan model pembelajaran ELPSA dan alat peraga geoboard. Adapun tujuan penelitian tindakan kelas ini adalah untuk meningkatkan aktivitas dan hasul belajar siswa dengan model pembelajaran ELPSA dengan bantuan alat peraga geoboard pada materi segi empat.

\section{Metode Penelitian}

Penelitian tindakan kelas ini menggunakan model ELPSA dengan bantuan alat peraga geoboard, dilaksanakan di kelas VII A SMP Negeri 2 Dompu, Kab. Dompu yang berjumlah 28 orang yang terdiri dari laki-laki 13 orang dan perempuan 15 orang. Penelitian dilaksanakan bulan April 2019, mulai tahap persiapan (membuat alat peraga, menyusun RPP, menyusun instrumen) sampai tahap pelaksanaan pembelajaran pada materi bangun datar segiempat, dan tahap penyusunan pelaporan. Dalam penelitian ini dibantu teman sejawat sebagai observer. 
Teknik pengumpulan data menggunakan: a. angket (respons siswa dalam pelaksanaan pembelajaran), b. observasi (aktivitas siswa selama pembelajaran), dan c. tes (hasil belajar). Data penelitian terdiri dari data kualitatif (hasil pengamatan/observasi) selama pembelajaran dan data kuantitatif yaitu hasil tes belajar bangun datar segi empat dengan sumber data diperoleh langsung dari siswa saat proses pembelajaran. Berdasarkan jenis data, teknik analisis yang digunakan dideskripsikan, sebagai berikut: 1) Data kuantitatif misalnya nilai hasil belajar siswa dapat dianalisis secara statistik deskriptif sederhana, yakni dengan rerata (mean), dan persentase $(\%) ; 2$ ) Data kualitatif yaitu data yang berupa informasi berbentuk kalimat yang memberi gambaran tentang ekspresi siswa terhadap tingkat pemahaman suatu mata pelajaran (kognitif), aktivitas atau sikap siswa terhadap penggunaan model pembelajaran ELPSA dan alat peraga geoboard (afektif).

Data kuantitatif hasil belajar ditabulasi dan dihitung ketuntasannya pada masingmasing siklus. Data tersebut dianalisis untuk keberhasilan pembelajaran yang diterapkan dengan indikator meningkatnya hasil belajar siswa baik aspek afektif (keaktifan siswa) maupun aspek kognitif berupa peningkatan aktivitas dan hasil belajar antar siklus dan persentase siswa yang tuntas belajar atau memperoleh nilai > (lebih dari nilai) KKM (Kriteria Ketuntasan Minimal) yaitu 60.

Penggunaan media geoboard dilakukan untuk membantu siswa di dalam memahami konsep matematika yang abstrak, sehingga mereka lebih tertarik, merasa lebih tertantang, dan merasa ikut andil di dalam proses pembelajaran dan menemukan konsep. Siswa akan lebih tertarik mempelajari geometri apabila mereka terlibat secara aktif baik individual atau kelompok, mereka hendaknya diberi kesempatan untuk melakukan investigasi yang akan memberikan pemahaman bagi siswa karena diperlukan bimbingan dan arahan dari guru dalam penggunaan media tersebut sehingga dapat mencapai tujuan pembelajaran yang diharapkan pada materi segiempat, dapat meningkatkan pemahaman konsep segiempat siswa. Hal ini terlihat dari hasil persentase tes pemahaman siswa yang mencapai nilai KKM di setiap siklusnya (Kadir, 2018).

\section{Hasil Penelitian dan Pembahasan}

Model berdasarkan pembelajaran ELPSA dikembangkan pada teori-teori konstruktivisme dan sifatnya sosial. Model ini memandang bahwa proses pembelajaran sebagai para cara suatu siswa dalam proses aktif dimana menemukan sendiri memahami sesuatu melalui pemikiran individu dan interaksi sosial dengan temannya. Adapun penerapan model ELPSA di dalam pembelajaran; 1) Experiences (pengalaman): menghubungkan materi bangun datar segi empat dengan pengalaman siswa dalam dalam kehidupan lingkungan sehari-hari dan sekitar, dengan cara mengidentifikasi jenis-jenisnya dan sifat-sifatnya; 2) Language (bahasa): mengenal istilah istilah dengan Matematika yang berkaitan segi empat, bangun datar misalnya sisi, sudut, bidang, diagonal, kemudian mendeskripsikan masing masing bangun datar dengan terminologi Matematika, serta membiasakan siswa untuk bertanya; 3) Picture (gambar): mengenalkan bangun datar kemudian menyiapkan bangunbangun datar segi empat dari peraga plastik, mengenalkan bentuk bentuk bangun datar menggunakan geoboard dan karet gelang; 4) Symbol (simbol): memberikan nama bangun datar segiempat dengan simbol ABCD, EFGH dan lain sebagainya; 5) Application (aplikasi): mengaplikasikan bangun-bangun datar segiempat dengan cara mengelompokkan yang sejenis, menerapkan dalam kehidupan sehari-hari.

Hal terpenting sebagai dasar dalam mendesain sebuah pembelajaran ELPSA yang bermutu adalah penekanan pembelajaran yang mampu menjadikan siswa memahami konsep 
secara maksimal melalui simbol meskipun membutuhkan waktu yang relatif lama. Alat peraga dibuat berdasarkan prinsip bahwa pengetahuan yang ada pada setiap manusia itu diterima atau ditangkap melalui pancaindra. Semakin banyak menerima indra yang digunakan untuk sesuatu, maka semakin banyak dan semakin jelas pengetahuan yang diperoleh. Alat peraga dimaksudkan untuk mengerahkan indra sebanyak mungkin kepada suatu obyek sehingga mempermudah persepsi.

Proses pembelajaran menggunakan alat peraga berarti memaksimalkan fungsi seluruh pancaindra siswa untuk meningkatkan efektivitas belajar dengan cara melihat, mendengar, mempraktikkan, dan menggunakan pikirannya secara logis dan real.. Alat peraga dalam pembelajaran memegang peranan penting sebagai alat bantu yang efektif. Alat peraga papan berpaku, yang dikenal dengan geoboard dibuat dari papan berbentuk persegi panjang atau persegi. Pada papan itu dibuat persegi-persegi kecil yang pada setiap titik sudutnya ditancapkan paku setengah masuk dan setengahnya masih timbul. Dalam hal ini ditambahkan karet gelang untuk membuat bangun datar pada papan berpaku tersebut.

Manfaat alat peraga geoboard dalam pembelajaran, siswa dapat lebih mudah dalam membuat bentuk geometri bangun datar segi empat tanpa memerlukan banyak waktu untuk menggambar di kertas dengan pensil dan penghapus, misalnya membuat persegi, persegi panjang, jajargenjang, trapesium, layang-layang dan belah ketupat. Dengan papan berpaku dapat dengan mudah menghitung keliling dan luas bangun datar segi empat.

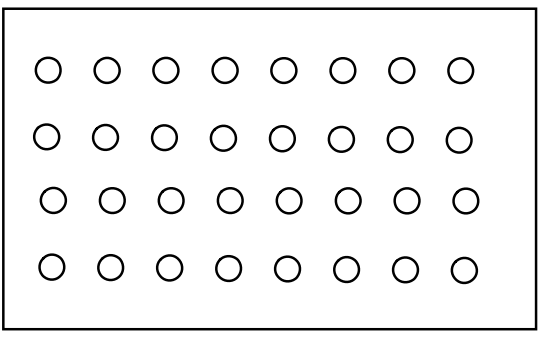

\section{Gambar 1. Papan Berpaku (Geoboard) dan Karet Gelang}

Geoboard adalah penggunaan alat peraga manipulatif untuk mengeksplor konsep dara dalam bidang geometri. Alat peraga geoboard (papan berpaku) ini cocok untuk membantu siswa SMP dalam berbagai macam bentuk bangun datar, sehingga siswa akan lebih memahami bangun datar secara konkret, yang selama ini kebanyakan siswa hanya menghitung menggunakan dengan menghafal rumus. Selain itu, alat peraga geoboard dapat dikatakan sebagai sebuah permainan yang menyenangkan dan penuh tantangan, dimana siswa aktif terlibat dalam menuangkan kreativitasnya secara konkret dalam aspek imajinasi penemuan geometri. Alat peraga ini dapat digunakan secara klasikal maupun kelompok.

Agar pelaksanaan pembelajaran berjalan dengan baik dan hasilnya dapat diandalkan, maka perbaikan pembelajaran dapat diarahkan pada pengelolaan proses pembelajaran. Hasil belajar merupakan hal yang dapat dipandang dari dua sisi yaitu siswa dan guru. Dari sisi siswa, hasil belajar merupakan tingkat perkembangan mental yang lebih baik bila dibandingkan pada saat sebelum belajar, tingkat perkembangan mental tersebut terwujud pada jenis ranah kognitif, afektif dan psikomotor. Sedangkan dari sisi guru, hasil belajar merupakan saat terselesaikannya bahan pelajaran.

\section{Deskripsi Siklus I}

Aktivitas siswa dalam proses pembelajaran, mencakup tujuh indikator yang masingmasing indikator tercapai dalam persentase. Indikator pertama dalam proses pembelajaran yaitu mengajukan pertanyaan pada guru rata-rata persentase dari pertemuan pertama dan 
pertemuan kedua adalah 46,88\%, siswa masih bingung dengan pembelajaran yang dilaksanakan dengan menggunakan alat peraga dan model ELPSA, yang menjawab pertanyaan $28,13 \%$, mengerjakan lembar kegiatan secara berkelompok menunjukkan $60,94 \%$, bekerja sama dengan teman 1 kelompok $81,25 \%$, bertukar pendapat antar teman dalam kelompok 64,06\%, membuat kesimpulan 31,25\%, dan mempresentasikan hasil diskusi maupun hasil latihan $26,56 \%$, sehingga rata-rata aktivitas siswa secara klasikal pada siklus I adalah $55,36 \%$.

Dari 28 siswa yang mengikuti ulangan 1 siswa dinyatakan tuntas atau 39,29\% dan 17 siswa tidak tuntas dalam belajar yaitu $60,71 \%$. Berdasarkan hasil tersebut ada beberapa faktor yang mempengaruhi, misalnya kurang maksimalnya guru dalam membimbing kesulitan belajar siswa, siswa belum terbiasa menggunakan alat peraga dan berpikir untuk menurunkan rumus bangun datar berbentuk persegi dan persegi panjang, kurang waktu untuk membahas soal-soal latihan, sehingga yang tuntas dalam belajar masih kurang dari $50 \%$ dan rata-rata kelas masih di bawah ketuntasan minimal. Siswa yang belum tuntas diberikan pembelajaran remedial mandiri dan latihan soal-soal yang berkaitan dengan persegi dan persegi panjang, sehingga pada pertemuan berikutnya sudah dapat menyesuaikan dengan yang sudah tuntas dalam belajarnya.

Hasil analisis data angket siswa pada penggunaan alat peraga geoboard pada siklus I pada lampiran 6 dan dapat dirangkum sebagai berikut, dari 8 indikator, yaitu Alat peraga geoboard menarik untuk belajar. Kegiatan belajar dengan alat peraga geoboard menyenangkan. Penggunaan alat peraga geoboard memudahkan pemahaman terhadap materi yang dipelajari. Alat peraga geoboard merangsang untuk menumbuhkan rasa ingin tahu tentang matematika. Alat peraga geoboard ini sesuai digunakan sebagai media pembelajaran pada materi bangun datar segi empat. Belajar kelompok dengan menggunakan alat peraga geoboard membuat bisa belajar saling memberi dan menerima gagasan dari teman lain. Alat peraga geoboard mudah dipelajari secara kelompok, Secara keseluruhan alat peraga geoboard mudah dipahami. Terdapat 10 siswa atau 35,71\% menyatakan sangat setuju belajar bangun datar persegi dan persegi panjang menggunakan alat peraga geoboard, 11 siswa atau $39,29 \%$ menyatakan setuju belajar bangun datar segiempat menggunakan alat peraga geoboard, dan 7 siswa atau $25 \%$ menyatakan kurang setuju. bagi siswa yang menyatakan kurang setuju karena belum terbiasa belajar berkelompok dan menggunakan alat peraga dalam pembelajaran. Untuk itu pembiasaan pengguanaan alat peraga yang sangat diperlukan sekali dalam penanaman konsep matematika, khususnya kelas VII SMP yang masih sangat sulit menerima konsep yang abstrak.

\section{Deskripsi Siklus II}

Aktivitas siswa dalam proses pembelajaran pada siklus II tercapai dalam persentase. Setiap indikator sudah mengalami peningkatan persentase keaktifan siswa. Indikator pertama dalam proses pembelajaran yaitu mengajukan pertanyaan pada guru rata-rata persentase dari siklus I 46,88\% menjadi 47,92\%, siswa sudah mulai kenal dengan pembelajaran yang dilaksanakan dengan menggunakan alat peraga dan model ELPSA, yang menjawab pertanyaan siklus I 28,13\% menjadi $27,08 \%$ ini disebabkan siswa asyik dengan alat peraganya sehingga kurang fokus dengan pertanyaanpertanyaan yang diajukan guru, mengerjakan lembar kegiatan secara berkelompok pada siklus I menunjukkan 60,94\% menjadi $66,67 \%$, siswa sudah mulai terlihat aktivitas secara kelompok, bekerja sama dengan teman satu kelompok dari $81,25 \%$ menjadi $84,38 \%$, bertukar pendapat antar teman dalam kelompok dari 64,06\% menjadi 78,13\%, membuat kesimpulan dari 31,25\% menjadi 58,33\%, dan mempresentasikan hasil diskusi maupun hasil latihan dari 26,56\% menjadi 27,08\%, 
sehingga rata-rata aktivitas siswa secara klasikal pada siklus I adalah 55,36\% menjadi $63,61 \%$ pada siklus II.

Hasil pembelajaran diperoleh bahwa, siswa yang tuntas dalam belajar sebanyak 15 siswa atau 53,57\% dan yang tidak tuntas 13 siswa atau 46,43\%. Kemudian rata-rata nilai yang diperoleh siklus II ini mengalami peningkatan yaitu $61,90 \%$. Walaupun nilai rata-rata meningkat tapi proses pembelajaran yang telah dilaksanakan masih ada kekurangan atau belum maksimal, sehingga masih ada siswa yang belum tuntas. Untuk siswa yang belum tuntas diberikan remedial secara individu dan diberikan tugas di luar jam pelajaran, yang diharapkan dapat menuntaskan materi sebelum melanjutkan materi berikutnya. Hasil analisis data angket pada siklus II, Terdapat 14 siswa atau 50\% menyatakan sangat setuju belajar bangun datar belah ketupat dan layang-layang menggunakan alat peraga geoboard, 13 siswa atau 46,43\% menyatakan setuju belajar bangun datar segiempat menggunakan alat peraga geoboard, dan 1 siswa atau 3,57\% menyatakan kurang setuju. Dari analisis tersebut sudah mengalami peningkatan siswa yang merespons pembelajaran bangun datar segiempat dengan menggunakan alat peraga geoboard, namun demikian masih ada siswa yang kurang setuju, karena tidak fokus dengan pembelajaran yang sedang berlangsung.

\section{Deskripsi Siklus III}

Aktivitas siswa dalam proses pembelajaran pada siklus II setiap indikator aktivitas yang dilaksanakan dalam sudah mengalami peningkatan yang luar biasa. Indikator pertama dalam proses pembelajaran yaitu mengajukan pertanyaan pada guru rata-rata persentase dari siklus II 47,92\% menjadi 67,75\%, dikarenakan siswa sudah mulai terbiasa dengan pembelajaran yang dilaksanakan dengan menggunakan alat peraga dan model ELPSA, yang menjawab pertanyaan siklus II 27,08\% menjadi 34,38\% ini disebabkan siswa sudah mulai terarah dengan alat peraganya sehingga mereka fokus dengan pertanyaan-pertanyaan yang diajukan guru, mengerjakan lembar kegiatan secara berkelompok pada siklus II $66,67 \%$ menjadi 73,44\%, siswa sudah mulai terlihat aktivitas secara kelompok, bekerja sama dengan teman satu kelompok dari 84,38\% menjadi 87,50\%, bertukar pendapat antar teman dalam kelompok dar 78,13\% menjadi $87,50 \%$, membuat kesimpulan dari $58,33 \%$ menjadi $73,44 \%$, dan mempresentasikan hasil diskusi maupun hasil latihan dari $27,08 \%$ menjadi $31,25 \%$, sehingga rata-rata aktivitas siswa secara klasikal pada siklus II adalah $63,61 \%$ menjadi $74,49 \%$ pada siklus III.

Dari hasil belajar, siswa yang tuntas dalam belajar sebanyak 21 siswa atau $75 \%$ dan yang tidak tuntas 7 siswa atau $25 \%$. Kemudian rata-rata nilai yang diperoleh dari siklus III ini mengalami peningkatan yaitu 67,41. Peningkatan aktivitas belajar ternyata berefek pada hasil pembelajaran juga meningkat, walau masih ada siswa yang belum tuntas. Untuk siswa yang belum tuntas diberikan remedial secara individu dan diberikan tugas di luar jam pelajaran, yang diharapkan dapat menuntaskan materi sebelum melanjutkan pelaksanaan tes. Persentase ketuntasan dari siklus I ke siklus II naik $14,28 \%$ walaupun tuntas belum mencapai $75 \%$ dan rata-rata pada siklus I belum mencapai nilai Kriteria Ketuntasan Minimum (KKM) 60, tapi pada saat siklus II rata-ratanya mencapai 61,90 dan pada aiklus III mencapai 67,41 , mengalami kenaikan 5,51.

\section{Kesimpulan}

Dari hasil penelitian ini disampaikan, bahwa penggunaan model ELPSA dengan bantuan alat peraga geoboard dalam materi bangun datar segi empat (persegi, persegi panjang, jajar genjang, trapezium, belah ketupat, layang-layang) dapat meningkatkan aktivitas siswa dalam proses pembelajaran, peningkatan hasil belajar siswa dari siklus ke 
siklus yang di tunjukan dengan : a) Terjadi peningkatan aktivitas rata-rata 55,36\% pada siklus I, menjadi $63,61 \%$ pada siklus II dan meningkat menjadi $74,49 \%$ pada siklus III. b) Terjadi peningkatan rata-rata hasil belajar siswa dari 55,06\% pada siklus I, menjadi $61,90 \%$ pada siklus II dan meningkat menjadi 67,41\$ pada siklus III. Selain aktivitas dan hasil belajar siswa dalam proses pembelajaran menggunakan model ELPSA dengan bantuan alat peraga geoboard pada materi bangun datar segi empat, berdasarkan angket menunjukkan persentase siswa yang menyatakan sangat setuju $35,71 \%$ pada siklus I, $35,71 \%$ pada siklus II dan naik menjadi $50,00 \%$ pada siklus III, kemudia menyatakan setuju $39,29 \%$ pada siklus I, menjadi $53,57 \%$ pada siklus II dan meningkat lagi menjadi $46,43 \%$ pada siklus III.

\section{Saran}

Berdasarkan kesimpulan di atas, maka saran yang dapat diberikan adalah penggunaan model ELPSA dengan bantuan alat peraga geoboard dalam pembelajaran matematika hendaknya digunakan salah satu alternatif yang mampu mengaktifkan siswa belajar yang bermakna, yang pada akhirnya meningkatkan aktivitas dan hasil belajar matematika. Oleh karena itu, seharusnya guru kreatif memadukan model dengan media pembelajaran untuk menciptakan pembelajaran yang inovatif, efektif dan menyenangkan.

\section{Daftar Pustaka}

Annisa, R., Roza, Y., \& Maimunah, M. (2021). Analisis Kemampuan Pemecahan Masalah Matematis Siswa SMP Berdasarkan Gender. Jurnal Kependidikan: Jurnal Hasil Penelitian dan Kajian Kepustakaan di Bidang Pendidikan, Pengajaran dan Pembelajaran, 7(2), 481-490. doi:https://doi.org/10.33394/jk.v7i2.3688

Baharudin, B. (2015). Menganalisis Instrumen Penilaian Pembelajaran Matematika pada Materi Segi Empat Sekolah Menengah Pertama Negeri 1 Dompu. Jurnal Kependidikan: Jurnal Hasil Penelitian dan Kajian Kepustakaan di Bidang Pendidikan, Pengajaran dan Pembelajaran, $1(1)$. doi:https://doi.org/10.33394/jk.v1i1.388

Effendi, L.A. (2012). Pembelajaran matematika dengan metode Penemuan Terbimbing untuk meningkatkan kemampuan representative dan pemecahan masalah matematis siswa SMP. Jurnal Penelitian Pendidikan UPI, Vol. 13 No. 2.

Hajar, J. d. (2016). Implementasi of ELPSA Framework in Teaching Integral. International Journal of Science and Applied Technology, IJSAT. Vol. 1, No. 1, December 2016. Diambil kembali dari http://IJSAT.unri.ac.id/

Hartati. (2010). Pengembangan Alat peraga gaya Gesek untuk meningkatkan Keterampilan berpikir Kritis Siswa SMA. JPFI.

Husna, R., Roza, Y., \& Maimunah, M. (2021). Identifikasi Kesulitan Guru Matematika Dalam Pelaksanaan Pembelajaran Daring di Masa Pandemi Covid-19. Jurnal Kependidikan: Jurnal Hasil Penelitian dan Kajian Kepustakaan di Bidang Pendidikan, Pengajaran dan Pembelajaran, 7(2), 428-436. doi:https://doi.org/10.33394/jk.v7i2.3333

Imas, M. d. (2017). Pengaruh penggunaan alat peraga Geoboard terhadap. Banten: IAIN Sultan Maulana Hasanuddin. Diambil kembali dari http://repository.uinbanten.ac.id/37/

Johar, H. d. (2016). Implementasi of ELPSA Framework in Teaching Integral. International Journal of Science and Applied Technology, IJSAT. Vol. 1, No. 1, December 2016. Diambil kembali dari http://IJSAT.unri.ac.id/ 
Kadir, K. (2018). Penerapan langkah-langkah Pembelajaran Van Hiele Berbantuan Media manipulatif geoboard sebagai upaya meningkatkan pemahaman konsep segiempat siswa. Jurnal Pendidikan UNM.

Patahuddin, T. L. (2015). ELPSA As a Lesson Design Framework. IndoMS-JME Volume 6, No. 2, pp. 1-15.

Suharjana, S. d. (2009). Pemanfaatan Alat Peraga Matematika Dalam Pembelajaran di SD. Yogyakarta: Departemen Pendidikan Nasional.

Syaifuddin. (2014). Inovasi Pendidikan Bandung. Bandung: Alfabeta.

Wijaya. (2014). Pengenalan Desain Pembelajaran ELPSA. 